\title{
Effect of climatic temperature on the age of onset of Huntington's chorea ${ }^{1}$
}

\author{
C. J. BRACKENRIDGE \\ From the Department of Psychiatry, University of Melbourne, \\ Royal Melbourne Hospital, Victoria, 3050, Australia
}

SYNOPSIS The ages of 1,403 subjects at onset of Huntington's chorea were drawn from the literature and related to the mean annual, January, and July temperatures of their place of residence. When the data were converted into mean annual, winter, and summer isotherms covering a range of $10^{\circ} \mathrm{F}\left(5 \cdot 6^{\circ} \mathrm{C}\right)$, there was a statistically significant decrease in age of onset as the temperature increased. Over the ranges studied, winter temperatures exerted a stronger effect than summer temperatures. To reduce interference by ethnic factors, the analysis was repeated on North American subjects with similar results. It is suggested that repeated infections may provoke chorea and that the observed lowering of the age of onset is associated with increased susceptibility to infection on passing from cold to warm climates.

A distinctive feature of Huntington's chorea is the variable age at which signs first appear. Although it is often regarded as a disease of adulthood with an onset at about 40 years of age, this figure is misleading unless due account is taken of its standard deviation of some 12 years. Cases presenting from the first year of life (Pleydell, 1954; Bird and Paulson, 1971), to the eighth decade (Ørbeck and Quelprud, 1954; Lyon, 1962) have been documented. It is clear that some of this variation is genetic in origin (Reed and Chandler, 1958; Brackenridge, 1972); specific environmental factors involved in the appearance of symptoms are more difficult to demonstrate.

It is commonly observed that movements worsen under the strain of testing situations, and it is natural to speculate that the interaction between a sensitive personality and disturbing lifeevents may actuate pathogenesis. Pregnancy has been suggested several times (Tieke, 1934; Panse, 1942; Spengler, 1956) as a possible agent provocateur, but the work of Oepen et al. (1963) and the independence of age of onset and sex (Brackenridge, 1971) argue against its promi-

This work was supported by a grant from the National Health and Medical Research Council of Australia. nence. Climate imposes a degree of discomfort in most parts of the world and it seemed plausible that the illness could appear earlier in areas of extreme heat or cold than in temperate regions. The null hypothesis was therefore formulated that the age at onset of Huntington's chorea was unrelated to climatic temperature.

\section{METHODS}

Following Wendt (1959), the definition proposed by Panse (1942) has been adopted in the present study; onset has been dated from the first appearance of psychiatric or neurological signs attributed retrospectively to Huntington's chorea. Providing that ages of onset were recorded to within three years and unless they had resided in different isothermal regions (defined below), subjects were drawn from all the descriptions in the source references cited in Appendix III of Brackenridge (1972) with the following additions: Althaus (1880), MacLeod (1881), King (1885), Diller (1889), Phelps (1892), Collins (1898), Evans (1908), Müller (1903), Strümpell (1908), Bahr (1912), Seip (1928), Casper (1930), von Sántha (1931), Buck (1934), Kloos (1938), Lion and Kahn (1938), Chamberlain (1943), Cronin (1943), Reisner (1944), Laane (1951), Major (1951), Leese et al. (1952), Shiman (1954), Souder (1954), Saetra (1958), Mackenzie-Van Der Noordaa (1960), Oltman and Friedman (1961), Müller-Küppers and 
Stenzel (1963), Brothers (1964), Sourkes et al. (1965), Calkins and Van Allen (1967), Korenyi and Whittier (1967), Starr (1967), Finn (1970), Guercio (1970), Ordoñez (1971), Fau et al. (1971), and Wallace and Hall (1972).

Using contour-maps, each subject was allocated to a particular isothermal region, covering a $10^{\circ} \mathrm{F}$ $\left(5.6^{\circ} \mathrm{C}\right)$ span of temperature, according to area of residence. Three types of isotherm were selected: mean annual temperature (Bartholomew, 1942) and January and July temperatures (Lewis and Campbell, 1951). The latter were taken to represent winter or summer when the hemisphere was northern or southern, respectively. The null hypothesis was tested by comparing the mean isothermal ages of onset by analysis of variance or the non-parametric Kruskal-Wallis test (Kruskal and Wallis, 1952).

\section{RESULTS}

Because of the predominance of European and North American subjects, distribution in terms of mean annual temperature was irregular (Table 1). There was, however, an obvious trend for the mean age of onset to fall as the temperature rose. As heterogeneity of the variances was of borderline significance, mean isothermal onset ages were compared using the Kruskal-Wallis
TABLE 1

RELATION OF AGE OF ONSET TO MEAN ANNUAL TEMPERATURE

\begin{tabular}{ccc}
\hline $\begin{array}{c}\text { Mean annual temperature } \\
\left({ }^{\circ} \mathrm{F}\right)\end{array}$ & $\begin{array}{c}\text { Subjects } \\
(\text { no. })\end{array}$ & $\begin{array}{c}\text { Mean } \pm S E \text { of age of onset } \\
(\mathrm{yr})\end{array}$ \\
\hline 30 to 39 & 32 & $40 \cdot 4 \pm 1 \cdot 7$ \\
40 to 49 & 1,048 & $33 \cdot 9 \pm 0 \cdot 2$ \\
50 to 59 & 199 & $31 \cdot 6 \pm 1 \cdot 0$ \\
60 or higher & 124 & $29 \cdot 4 \pm 1 \cdot 1$ \\
\hline
\end{tabular}

test. The statistic $\mathrm{H}$ (a measure of populationdifferences and distributed essentially as $\chi^{2}$ ) \& with 3 DF equalled 29.37, for which $P<0.001$. $\vec{\circ}$ The decline in age of onset was therefore significant.

Mean annual temperature is a poor index of climatic stress, as extremes of heat and cold can fluctuate widely about a given mean. Possible $\dot{\omega}$ differential effects of the seasons were thereforø examined. The distribution of subjects amon the five winter isotherms were: $10-19^{\circ} \mathrm{F}(104 \%$ $20-29^{\circ} \mathrm{F}(261), 30-39^{\circ} \mathrm{F}(829), 40-49^{\circ} \mathrm{F}$ (150 and $50-59^{\circ} \mathrm{F}(59)$. The distribution among the four summer isotherms were: $50-59^{\circ} \mathrm{F}(1958$

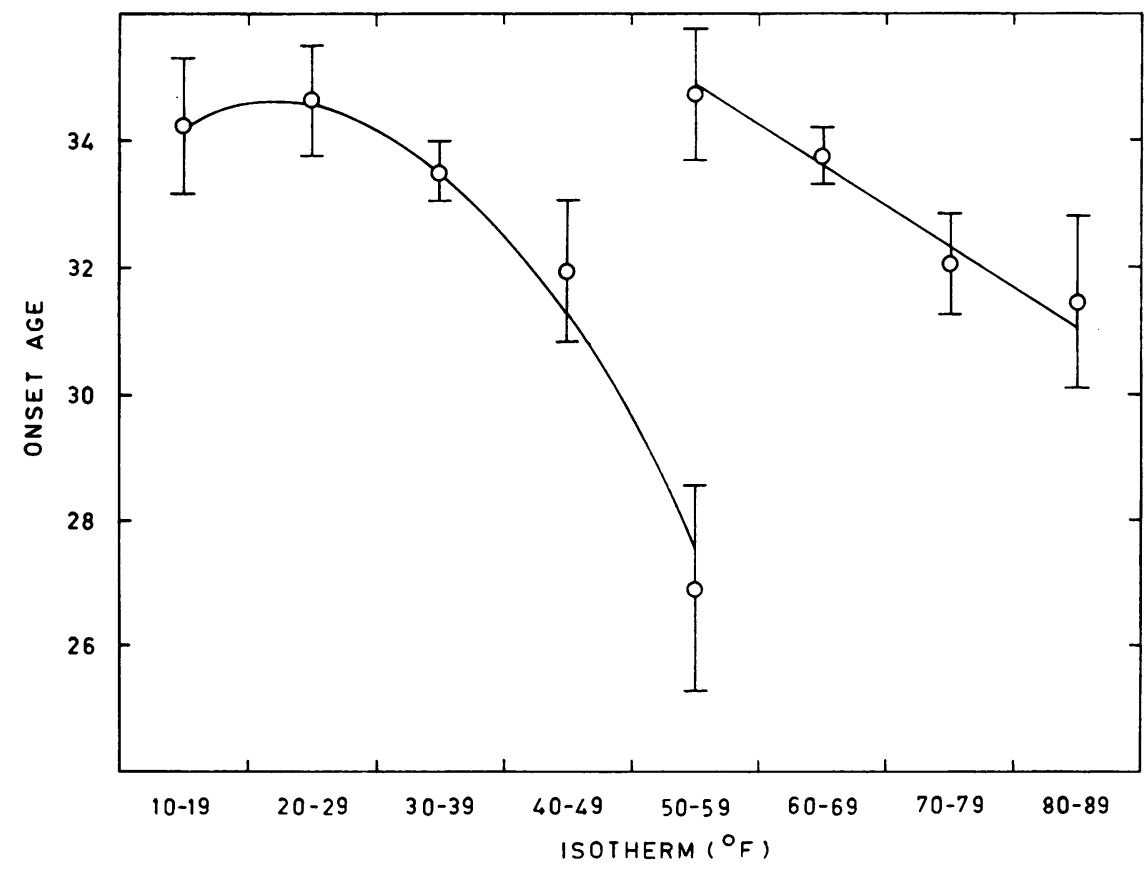

FIGURE Variation of age of onset of Huntington's chorea with winter temperature (left) and summer temperature (right). 
$60-69^{\circ} \mathrm{F}(778), 70-79^{\circ} \mathrm{F}(355)$, and $80-89^{\circ} \mathrm{F}$ (75). The Figure shows that the greater decline in age of onset occurs over the winter rather than the summer range of temperatures. When age of onset was regressed on temperature, winter values were best fitted by the quadratic equation

$$
\text { Onset-age }=31 \cdot 0+0 \cdot 32 \mathrm{~W}+0 \cdot 007 \mathrm{~W}^{2} \text {, }
$$

where $\mathrm{W}$ denotes the mid-point of a winter isotherm in ${ }^{\circ} \mathrm{F}$. The ratio of the variance due to regression to the variance about the regression curve was 8.94 with 2 and $1,400 \mathrm{DF}(\mathrm{P}<0.001)$. Summer values were adequately represented by the linear equation

$$
\text { Onset-age }=42 \cdot 0-0 \cdot 13 \mathrm{~S} \text {, }
$$

where S denotes the mid-point of a summer isotherm in ${ }^{\circ} \mathrm{F}$. The F-ratio of 7.23 with 1 and $1,401 \mathrm{DF}(\mathrm{P}<0.01)$ indicated that the regression line accounted for an appreciable proportion of the variance.

Tables 2 and 3 summarize the analyses of variance performed on the data. Over the temperature ranges studied, cold exerted a greater effect on age of onset than heat, the variance ratio for which was barely significant. Sex was not an important factor, although there was an appreciable interaction with winter iso-

TABLE 2

ANALYSIS OF VARIANCE OF AGE OF ONSET IN RELATION TO WINTER TEMPERATURE

\begin{tabular}{lcrcc}
\hline Source of variation & Variance & $D F$ & $\begin{array}{c}\text { Variance- } \\
\text { ratio }\end{array}$ & $\begin{array}{c}P \\
\text { less than }\end{array}$ \\
\hline Between isotherms & 869.8 & 4 & 4.92 & 0.001 \\
Between sexes & 259.7 & 1 & 1.47 & 0.226 \\
Isotherm-sex interaction & 490.6 & 4 & 2.77 & 0.026 \\
Within groups & 176.8 & 1393 & & \\
\hline
\end{tabular}

TABLE 3

ANALYSIS OF VARIANCE OF AGE OF ONSET IN RELATION TO SUMMER TEMPERATURE

\begin{tabular}{lcrcc}
\hline Source of variation & Variance & $D F$ & $\begin{array}{c}\text { Variance- } \\
\text { ratio }\end{array}$ & $\begin{array}{c}P \\
\text { less than }\end{array}$ \\
\hline Between isotherms & 469.9 & 3 & 2.63 & 0.049 \\
Between sexes & 259.7 & 1 & 1.45 & $0 \cdot 228$ \\
Isotherm-sex interaction & $364 \cdot 3$ & 3 & 2.04 & $0 \cdot 107$ \\
Within groups & 178.7 & 1395 & & \\
\hline
\end{tabular}

therms. Division of subjects according to sex led to the demonstration that cold climate delayed onset in females $(F=4.98$ with 4 and $699 \mathrm{DF}$, $\mathrm{P}<0.001)$ to a greater extent than in males $(\mathrm{F}=$ 2.74 with 4 and $694 \mathrm{DF}, \mathrm{P}<0.028$ ).

Because of differing cultures and ethnic groups, it is possible that national characteristics were responsible for at least part of these results. As the largest homogeneous group of subjects were North American, analyses of variance were repeated on these 364 white Caucasians. Fortunately, there is a relatively wide range of temperatures on this subcontinent to make such tests reasonably sensitive. Variances of onset ages applicable to winter and summer conditions were heterogeneous; Kruskal-Wallis tests were therefore made on the data. Winter conditions $(\mathrm{H}=55.79$ with $3 \mathrm{DF}, \mathrm{P}<0.001)$ were again a stronger determinant of onset age than summer conditions $(H=9.39$ with $2 \mathrm{DF}, \mathrm{P}<0.01)$. In each case the ages of onset were inversely related to temperature as previously found for all subjects. Reduction of ethnic factors therefore failed to affect the main features of the results.

\section{DISCUSSION}

From the results presented, it appears that the first signs of Huntington's chorea occur at an earlier age in hot climates. The extent of the decrease in age with increasing temperature depends on the climatic index used. As the mean annual temperature rises by some $40^{\circ} \mathrm{F}\left(22^{\circ} \mathrm{C}\right)$ from northern Sweden to tropical regions such as India, the average age at onset falls by about a decade. In seasonal terms, it is clear that winter exerts a greater effect than summer. Nevertheless, the age at onset gradients are similar over the first four isotherms of each season; it is only the last winter isotherm $\left(50-59^{\circ} \mathrm{F}\right)$ which gives rise to its predominance. The shape of the winter curve bears only a partial resemblance to the parabola which arises if stress, caused by extreme temperatures, induces chorea prematurely. Instead, it seems that low degrees of heat and cold are not conducive to an early onset but that higher temperatures progressively pose a greater threat.

It is important to establish whether the present results represent actual physical effects of temperature or of some factor dependent on 
temperature. It is not possible to distinguish between these alternatives solely from the present study. The application of heat may aggravate some of the symptoms of multiple sclerosis (Simons, 1937) and other neurological disorders (Nelson et al., 1958); no direct effect of temperature seems to have been reported for Huntington's chorea. Lacking such evidence, it is suggested that the lowering of the age of onset of chorea is associated with the increased susceptibility to infection on passing from temperate to tropical areas.

Some authors (Hughes, 1925; Brothers, 1964) have noted the appearance of Sydenham's chorea in persons who develop Huntington's chorea later in life. Bruyn (1968) interprets this as a predisposition to react with chorea after stress or infection: 'an individual who, at mature age, develops chorea due to the metabolic defect he has inherited may, at tender age, betray this if a cerebral infection (rheumatism) comes into play'. Streptococcal infection is commonly associated with Sydenham's chorea (Matthews et al., 1960), and Taranta (1959) has shown in a prospective study that it can follow infections with group A streptococci after an interval of three to six months.

In a retrospective study of stress in Huntington's chorea, Korenyi et al. (1972) found that trauma and infection headed the list of putative somatic precipitants of the disorder. If it is granted that infections provoke an earlier appearance of symptoms than would otherwise be the case, a geographical gradient of the type described here could be anticipated.

\section{REFERENCES}

Althaus, J. (1880). Chorea mit Epilepsie gepaart. Archiv für Psychiatrie, 10, 139-145.

Bahr, M. A. (1912). Some clinical observations in three cases of Huntington's chorea. Medical Record, 82, 756-758.

Bartholomew, J. G. (ed.) (1942). The Oxford Advanced Atlas, 7th edn., p. 12. Oxford University Press: London.

Bird, M. T., and Paulson, G. W. (1971). The rigid form of Huntington's chorea. Neurology (Minneap.), 21, 271-276.

Brackenridge, C. J. (1971). A genetic and statistical study of some sex-related factors in Huntington's disease. Clinical Genetics, 2, 267-286.

Brackenridge, C. J. (1972). Familial correlations for age at onset and age at death in Huntington's disease. Journal of Medical Genetics, 9, 23-32.

Brothers, C. R. D. (1964). Huntington's chorea in Victoria and Tasmania. Journal of the Neurological Sciences, 1, 405420.
Bruyn, G. W. (1968). Huntington's chorea. Historical, clinical and laboratory synopsis. In Handbook of Clinical Neurology. Vol. 6, pp. 298-378. Edited by P. J. Vinken and G. W. Bruyn. North-Holland: Amsterdam.

Buck, C. A. (1934). Huntington's chorea, with the report of a case. Canadian Medical Association Journal, 31, 178-180.

Calkins, R. A., and Van Allen, M. W. (1967). Huntington's chorea. Journal of the Iowa State Medical Society, 57, 336340.

Casper, J. (1930). Chorea Huntington. Zentralblatt fiur gesamte Neurologie und Psychiatrie, 57, 855-856.

Chamberlain, L. C. (1943). Abstract of clinical history of case 2. New Orleans Medical and Surgical Journal, 96, 5762.

Collins, J. (1898). The pathology and morbid anatomy of Huntington's chorea, with remarks on the development and treatment of the disease. American Journal of the Medical Sciences, 116, 275-291.

Cronin, E. J. (1943). Huntington's chorea. New Zealand Medical Journal, 42, 231.

Diller, T. (1889). Some observations on the hereditary form $\vec{O}$ of chorea, with the report of a case. American Journal of the Medical Sciences, 98, 585-593.

Evans, J. J. W. (1908). Observations on a case of Huntington's chorea. Lancet, 2, 940.

Fau, R., Chateau, R., Tommasi, M., Groslambert, R., Garrel, S., and Perret, J. (1971). Étude anatomo-clinique d'une forme rigide et myoclonique de maladie de Huntington infantile. Revue Neurologique, 124, 353-366. $\square \omega$

Finn, R. (1970). The three-century history of an Iowa famiळ i with Huntington's chorea. Journal of the Iowa Medicar Society, 60, 89-93.

Guercio. N. M. (1970). Corea crónica juvenil. Prensa Médic Argentina, 57, 1733-1734.

Hughes, E. M. (1925). Social significance of Huntington chorea. American Journal of Psychiatry, 4, 537-574.

King, C. (1885). Hereditary chorea. New York Medic Journal, 41, 468-470.

Kloos, G. (1938). Gehäufte erbliche Taubheit in einêf Huntington-Familie. Münchener Medizinische Wochert schrift, 85, 94-96.

Korenyi, C., and Whittier, J. R. (1967). Drug treatment in 117 cases of Huntington's disease with special reference to fluphenazine (Prolixin). Psychiatric Quarterly, 41, 203-210.

Korenyi, C., Whittier, J. R., and Conchado, D. (1972). Stress in Huntington's disease (chorea). Diseases of the Nervous System, 33, 339-344.

Kruskal, W. H., and Wallis, W. A. (1952). Use of ranks in one-criterion variance analysis. Journal of the American Statistical Association, 47, 583-621.

Laane, C. L. (1951). Den tidlige diagnose av chorea Huntington. Nordisk Medicin, 45, 835-837.

Leese, S. M., Pond, D. A., Shields, J., and Race, R. R. (1952). A pedigree of Huntington's chorea. Annals of Eugenics, 17, 92-112.

Lewis, C. G., and Campbell, J. D. (eds) (1951). The Oxford Atlas, maps 2, 4. Oxford University Press: London.

Lion, E. G., and Kahn, E. (1938). Experiential aspects of Huntington's chorea. American Journal of Psychiatry, 95, 717-727.

Lyon, R. Ll. (1962). Huntington's chorea in the Moray Firth area. British Medical Journal, 1, 1301-1306.

Mackenzie-van der Noordaa, M. C. (1960). De door Westphal beschreven variant van de ziekte van Huntington. Nederlandsch tijdschrift voor geneeskunde, 104, 1625-1627.

MacLeod, M. D. (1881). Cases of choreic convulsions in persons of advanced age. Journal of Mental Science, 27, 194200.

Major, S. (1951). An unusual case of Huntington's chorea. New York State Medical Journal, 51, 2779-2782. 
Matthews, R., Williams, H., Rickards, W., Waterhouse, I., and Allen, J. (1960). Sydenham's chorea: its relationship to rheumatic infection and psychological illness. Medical Journal of Australia, 2, 771-774.

Müller, L. (1903). Ueber drei Fälle von Chorea chronica progressiva (Chorea hereditaria, Chorea Huntington). Deutsche Zeitschrift für Nervenheilkunde, 23, 315-335.

Müller-Küppers, M., and Stenzel, K. (1963). Zum Problem der Frühmanifestation der Erbchorea. Acta Paedopsychiatrica, 30, 348-355.

Nelson, D. A., Jeffreys, W. H., and McDowell, F. (1958). Effects of induced hyperthermia on some neurological diseases. Archives of Neurology and Psychiatry, 79, 31-39.

Oepen, H., Landzettel, H. J., Streletzki, R., and Koppenfels, I. von (1963). Statistische Befunde zur Klinik der Huntingtonschen Chorea. Archiv für Psychiatrie und Nervenkrankheiten, 204, 11-24.

Oltman, J. E., and Friedman, S. (1961). Comments on Huntington's chorea. Diseases of the Nervous System, 22, 313-319.

Ørbeck, A. L., and Quelprud, T. (1954). Setesdalsrykka (Chorea Progressiva Hereditaria). Dybwad: Oslo.

Ordoñez, A. C. (1971). Corea de Huntington. Asociación Española de Neuropsiquiatría, Collección Los Premios.

Panse, F. (1942). Die Erbchorea: eine klinisch-genetische Studie. In Sammlung Psychiatrischer und Neurologischer Einzeldarstellung. Vol. 18. Edited by A. Bostroem, K. Beringer, and G. Schaltenbrand. Thieme: Leipzig.

Phelps, R. M. (1892). A new consideration of hereditary chorea. Journal of Nervous and Mental Diseases, 17, 765776.

Pleydell, M. J. (1954). Huntington's chorea in Northamptonshire. British Medical Journal, 2, 1121-1128.

Reed, T. E., and Chandler, J. H. (1958). Huntington's chorea in Michigan. I. Demography and genetics. American Journal of Human Genetics, 10, 201-225.

Reisner, H. (1944). Chorea Huntington bei einem Kinde. Nervenarzt, 17, 86-92.
Saetra, G. (1958). Lund-Huntingtons Chorea. En nyoppdaget slekt i østfold fylke. Tidsskrift for den Norske Laegeforening, 78, 642-643.

Sántha, K. von (1931). Zur Pathologie der hereditären Chorea. Archiv für Psychiatrie, 95, 455-480.

Seip, T. (1928). Ein Fall von Chorea Huntington und einige Bemerkungen zu dieser Krankheit. Acta Psychiatrica et Neurologica, 3, 139-152.

Shiman, M. (1954). A family pedigree of Huntington's chorea. Yamaguchi Rinsho Igaku, 2, 53-55.

Simons, D. J. (1937). Note on effect of heat and of cold upon certain symptoms of multiple sclerosis. Bulletin of the Neurological Institute of New York, 6, 385-386.

Souder, C. L. R. (1954). A family study of Huntington's chorea. Delaware State Medical Journal, 26, 201-202.

Sourkes, T. L., Pivnicki, D., Brown, W. T., Wiseman-Distler, M. H., Murphy, G. F., Sankoff, I., and Saint Cyr, S. (1965). A clinical and metabolic study of dopa (3,4-dihydroxyphenylalanine) and methyldopa in Huntington's chorea. Psychiatria et Neurologia, 149, 7-27.

Spengler, M. (1956). Verschlimmerung von Chorea Huntington in der Gravidität. Schweizerische medizinische Wochenschrift, 86, 931-932.

Starr, A. (1967). A disorder of rapid eye movements in Huntington's chorea. Brain, 90, 545-564.

Strümpell, A. (1908). Zur Casuistik der chronischen Huntington'schen Chorea. Neurographs, 1, 98-105.

Taranta, A. (1959). Relation of isolated recurrences of Sydenham's chorea to preceding streptococcal infections. New England Journal of Medicine, 260, 1204-1210.

Tieke, W. (1934). Über den Wandel des klinischen Bildes bei Huntingtonscher Krankheit. Allgemeine Zeitschrift fïr Psychiatrie, 102, 44-59.

Wallace, D. C., and Hall, A. C. (1972). Evidence of genetic heterogeneity in Huntington's chorea. Journal of Neurology, Neurosurgery, and Psychiatry, 35, 789-800.

Wendt, G. G. (1959). Das Erkrankungsalter bei der Huntingtonschen Chorea. Acta Genetica et Statistica Medica, 9, 18-32. 